\title{
VEGETATION ANALYSIS OF NAMUNA COMMUNITY FOREST OF SALBARI, SANISCHARE VDC IN JHAPA DISTRICT, EASTERN NEPAL
}

\author{
K.P. Bhattarai
}

\begin{abstract}
Vegetation study was carried out in an afforested land called Namuna Community Forest in Salbari, Sanischare, VDC, Jhapa, District. Random samplings for estimation of density, frequency, basal area and IVI were carried out by laying quadrates $(10 \mathrm{~m} \times 10 \mathrm{~m})$ at different sites of forest, three times and mean value was calculated. Nine tree species were recorded during field study. Total density of 10,410 $\mathrm{pl} / \mathrm{ha}$ and total basal area of $33.956 \mathrm{~m} 2 / \mathrm{ha}$ of tree species were recorded. The value of density (1790 pl/ha), basal area (31.45m2/ha) and IVI (130.63) were found highest for Shorea robusta, which is ecologically successful species in this forest. Lower value of basal area showed that this forest is young and regenerating. Other tree species had comparatively lower value of density, basal area and IVI due to regular human interference. Therefore an example of establishing forest community so as to initiate the conservation of local biodiversity has been discussed in this article.
\end{abstract}

Keywords: Community forest, conservation, IVI estimation, regenerating, Shorea robusta

\section{Introduction}

Nepal occupies only $0.1 \%$ of total land of the world but its forest and vegetation forms a prestigious heritage (Joshi 2001). Out of total land area (14.72 Million ha) of Nepal, forest covers about 4.27 million ha (Anon 1999). Nepal is one of the few countries in the world where people are, to a large extent, depending up on forest resources. The quality and quantity of forest is seriously threatened by population growth, habitat destruction and increasing commercial demands for raw materials. According to forest act 1993 the forest of Nepal is classified into Government managed Forest, Community Forest, Lease Hold Forest, Religious Forest, Protected Forest, and Collaborative Forest (HMG 2056). The community Forest has been launched for the protection of forest in Nepal and now it is successful in conservation and protection.

Namuna Community Forest is located from N 26 $46^{\prime} 37.4^{\prime \prime}$ to N $26^{\circ} 40^{\prime} 24.7^{\prime \prime}$ latitude, and E $88^{\circ} 00^{\prime} 37.6^{\prime \prime}$ to $\mathrm{E} 88^{\circ} 00^{\prime} 53.3^{\prime \prime}$ longitude (GPS, etrex-vista; K. P. Limbu, pers comm. 2005). This community forest is about $4 \mathrm{~km}$ north from the Birtamode at Salbari, Sanischare VDC of Jhapa District along the side of Aduwa Khola, which covers an area of 100 ha. It includes many Indo-Malayan species such as Shorea, Terminalia etc. It is a new regenerating forest and is dominated by trees of Shorea robusta. Other tree species, like Syzygium cumini, species illegally and may decreased forest annually. 


\section{Enumeration of tree species:}

$\begin{array}{lll}\text { Name of tree } & \text { Family } & \text { Local name } \\ \text { 1. Shorea robusta } & \text { Dipterocarpaceae } & \text { Sakhuwa } \\ \text { 2. Syzygium cumini } & \text { Myrtaceae } & \text { Jamuna } \\ \text { 3. S. operculatum } & \text { Myrtaceae } & \text { Kyamuna } \\ \text { 4. Terminalia bellirica } & \text { Combretaceae } & \text { Barro } \\ \text { 5. T. chebula } & \text { Combretaceae } & \text { Harro } \\ \text { 6. T. alata } & \text { Combretaceae } & \text { Saj } \\ \text { 7. Lagerstroemia parviflora } & \text { Lythraceae } & \text { Dhayaro } \\ \text { 8. Dillenia pentagyna } & \text { Dilleniaceae } & \text { Tatari } \\ \text { 9. Careya arborea } & \text { Lecythidaceae } & \text { Kumbi }\end{array}$

Tree density of Shorea robusta was $1790 \mathrm{pl} / \mathrm{ha}$ (Table 1). The value of density is greater than the value obtained in leasehold forest of Ramanthali, Makwanpur (Kunwar et al 2006). Previously, the density value of tree of Shorea robusta was estimated 3-4 times higher than Shorea- Syzygium community in Arun, East Nepal (Chaudhary and Kunwar, 2002).

Density of sapling Shorea robusta was $7520 \mathrm{pl} / \mathrm{ha}$, Syzygium cumini $630 \mathrm{pl} / \mathrm{ha}$, Lagerstromia parviflora $210 \mathrm{pl} / \mathrm{ha}$, Syzygium operculatum $90 \mathrm{pl} / \mathrm{ha}$, Terminalia bellirica $60 \mathrm{pl} / \mathrm{ha}$, T. chebula $30 \mathrm{pl} / \mathrm{ha}$, T. alata $30 \mathrm{pl} / \mathrm{ha}$, Dillenia pentagyna $30 \mathrm{pl} / \mathrm{ha}$ and Careya arborea $10 \mathrm{pl} /$ ha (Table 1). The density of sapling Shorea robusta was highest and Careya arborea was least among the studied tree species.

Table 1: Quantitative Estimation of tree species in Namuna Community Forest.

\begin{tabular}{|c|c|c|c|c|c|c|c|}
\hline species & $\begin{array}{c}\text { Density } \\
\mathrm{pl} / \mathrm{ha}\end{array}$ & $\begin{array}{l}\text { Relative } \\
\text { density (\%) }\end{array}$ & $\begin{array}{l}\text { Frequency } \\
\quad(\%)\end{array}$ & $\begin{array}{l}\text { Relative } \\
\text { frequency } \\
(\%)\end{array}$ & $\begin{array}{l}\text { Basal } \\
\text { area } \\
\left(\mathrm{m}^{2} / \mathrm{ha}\right)\end{array}$ & $\begin{array}{c}\text { Relative } \\
\text { basal area } \\
(\%)\end{array}$ & $\begin{array}{l}\text { Important } \\
\text { value index } \\
\text { (IVI) }\end{array}$ \\
\hline $\begin{array}{l}\text { Shorea robusta } \\
\text { adult }\end{array}$ & 1790 & 17.19 & 100 & 20.83 & 31.45 & 92.61 & 130.63 \\
\hline $\begin{array}{l}\text { S. robusta } \\
\text { sapling }\end{array}$ & 7520 & 72.23 & 100 & 20.83 & 2.15 & 6.33 & 99.39 \\
\hline Syzyzium cumini & 630 & 6.05 & 70 & 14.58 & 0.12 & 0.35 & 20.98 \\
\hline S. operculata & 90 & 0.86 & 40 & 8.33 & 0.04 & 0.11 & 9.30 \\
\hline Terminalia belerica & 60 & 0.57 & 30 & 6.25 & 0.02 & 0.05 & 6.87 \\
\hline T. chebula & 40 & 0.38 & 30 & 6.25 & 0.02 & 0.05 & 6.68 \\
\hline T. alata & 30 & 0.28 & 20 & 4.16 & 0.01 & 0.02 & 4.46 \\
\hline Lagertromia parviflora & 210 & 2.01 & 50 & 10.41 & 0.13 & 0.38 & 12.8 \\
\hline Dillenia pentagyna & 30 & 0.28 & 30 & 6.25 & 0.01 & 0.02 & 6.55 \\
\hline Carea arborea & 10 & 0.09 & 10 & 2.08 & 0.006 & 0.01 & 2.18 \\
\hline Total & 10,440 & 100 & & 100 & 33.956 & 100 & 300 \\
\hline
\end{tabular}


Similarly total basal area of studied tree species on NCF was $33.956 \mathrm{~m} 2 /$ ha (Table 1). The value of basal area in the present study is higher then the value obtained by Rana et al. (1988) in secondary Sal forest of India. Shorea robusta shared the highest basal area $(31.45 \mathrm{~m} 2 / \mathrm{ha})$. The value was relatively higher than value reported in the forest of Makwanpur (Kunwar et al. 2006). Comparatively lower value of basal area of each individual species and total species indicate that this is young, growing and regenerating forest.

Important Value Index (IVI) was highest for Shorea robusta (130.63). Similarly IVI of sapling S. robusta was 99.39 , Syzygium cumini was 20.98 and least value was found (2.18) for Careya arboria (Table 1). The IVI of Shorea robusta is higher than the value reported by Kunwar et al. (2006) from Gaidadhap of Makwanpur. Based on high IVI value Shorea robusta is most important and ecologically successful species in this forest.

\section{Conclusion}

Community forests are the main part of national forest handed over to the local people for their protection, management and utilization (Shrestha and Das, 2007). The progress made by these forests is encouraging in the field of conservation. From the result it is concluded that NCF is young, regenerating forest and ecologically most successful species is Shorea robusta. Besides, it is concluded that other tree species except Shorea robusta are not growing as trees. The user groups of community forest are protecting only valuable timber plant and other non timber species are utilized annually, if this process is continued, non timber species later might disappear from such type of forest. Subsequently forest would turn into monotonous having tall and big trees of single species only. Death and decay as well as the thoughtless domestic use of trees would gradually but surely cause barrenness to the land. Most of the forests of Nepal are handed over to the local people for protection, management and utilization without making them aware of the usefulness of the tree of heterogeneous species. Hence it is strongly recommended that the awareness and training program for the biodiversity conservation of forest should be conducted to the local care taker of forest. This will not only unable those to understand the importance of trees of different species but also help conserving, balancing healthy nature and life as well.

\section{Acknowledgements}

The author is grateful to Associate Prof. Dr. K.R. Rai, Chairman, Department of Biology, Mechi Multiple campus, Bhadrapur, for regular encouragement, suggestions and data collection. I would like to thank Dr. Mohan Siwakoti for his encouragement. I would like to extend sincere thank to Mrs. Bhawana Bhattarai for her kind cooperation during research period.

\section{References}

Annon, (1999). Forest Resources of Nepal (1987-1998). Department of

Forest Resources and Survey, Ministry of Forest and soil Conservation, Kathmandu, Nepal Bhatta, D. D. (1977). Natural History and Economic Botany of Nepal. Orient Longman Ltd, New Delhi, India.

Chaudhary, R.P. and R.M. Kunuwar, (2002). Vegetation composition of Arun Valley, Nepal, 
Vegetation and society. Their interaction in the Himalayas:38-55

ECS-Nepal, (2005). A study on Restoration of Budho Holi Wetland Ecosystem

For Biodiversity Conservation. Budho Holi Biodiversity Conservation Project-2005, Jhapa, Nepal.

HMG (2056), Forest Act (2049). Forest regulation 2051, Forest Department, Ministry of Forest and Soil Conservation, Kathmandu, Nepal.

Joshi, S. D. (2001). Biodiversity and Environment in Nepal. Botanica Orientalis, Annual issue: $40-42$

Kunuwar, R.M., N. P.S. Duwadee, N. Adhikari and P. Dawadee, (2006). Demography and diversity analysis of tree species in Leasehold Forest of Makwanpur District, Central Nepal, Proceeding of National Seminar on Natural Resources Management:393-401

Rana, B.S., S. P. Singh and R.P. Singh. (1988). Biomass and Productivity of Central Himalayan Sal Forest. Tropical Ecology, 29:1-6

Shrestha R. and A. K. Das (2007). Forest Categorization of Nepal and its Distribution, A short profile. Souvenir, National Seminar on Sustainable Use of Biological Resources (April 2227, 2007). Pokhara, Nepal:32-35

Zobel, D.B., P. K. Jha, M.J. Behan and U. K. R. Yadav, (1987). A Practical Mannual for Ecology. Ratna Book Distributers, Kathmandu, Nepal.

\section{Author's Address}

Mr. Krishna Prasad Bhattarai

Department of Botany

M. M. Campus, Bhadrapur, Jhapa, Nepal 